\title{
Efektivitas Pembelajaran Daring Pada Masa Covid di SMAN 2 Salatiga
}

\author{
Irna Eltri Samoling ${ }^{1}$, Bambang Ismanto ${ }^{2}$, Lelahester Rina ${ }^{3}$ \\ 162017018@student.uksw.edu1 , bambang.ismanto@uksw.edu², lelahester.rina@uksw.edu ${ }^{3}$ \\ Program Studi Pendidikan Ekonomi, FKIP Universitas Kristen Satya Wacana Salatiga ${ }^{1,2,3}$
}

\section{The Effectiveness Of Online Learning In Covid Pandemic At SMAN 2 Salatiga}

\begin{abstract}
E-learning is a learning that USES technology and can be done anywhere at any time. The purpose of this study is to describe the effectiveness of the application of online learning during the covid pandemic at sman 2 salatiga. The research approach used in this study is a qualitative approach. This type of research is a descriptive analysis model that describes the problem. The data-collection technique that researchers use is observation, the kind of observation used in this study is passive participation. Passive participative observations are made by observation but do not participate in these activities. Interviews, the kind of interviews used were structured interviews. Documentation is used to study data that has been collected. The results of this study indicate that the online learning program at SMAN 2 Salatiga has been effective from a cognitive perspective, but from an affective and psychomotor perspective it has not been effective. Because learning is not just providing material and assignments, but how educators teach factually, inquiry of all material. So, with the CIPP evaluation on online learning, the school can evaluate each policy that is determined (feasibility).
\end{abstract}

Keywords: Effectiveness, E-learning

Received date: 29 Juli $2021 \quad$ Revised date: 29 Desember $2021 \quad$ Accepted date: 27 Januari 2022

\section{PENDAHULUAN}

Pendidikan merupakan proses dimana mempersiapkan generasi penerusnya dalam menjamin tuntutan kehidupan secara efektif dan efisien di masa depan. Dapat ditegaskan bahwa pendidikan bukan hanya sekedar pengajaran. Sejalan dengan pemikiran ini, Fajarini (2014) menjelaskan pendidikan adalah suatu proses membina dan mengembangkan kemampuan sumber daya manusia akan kesadaran diri di antara individu satu dengan yang lain. Namun di masa pandemi covid-19 saat ini, pendidikan di rumah saja tidaklah cukup untuk memenuhi semua itu, pendidikan di sekolah juga sama pentingnya untuk memperluas wawasan akan dunia ini. Pendidikan memiliki peran dalam mengatur kehidupan setiap manusia serta sebagai penentu gambaran dalam kehidupan bangsa di masa depan. Menurut Prayitno (2009), pendidikan adalah akar yang mengalirkan zat-zat makanan bagi tumbuh-kembangnya pohon pribadi individu dan kehidupan. Tanpa pendidikan, harkat dan martabat manusia yang seharusnya dimuliakan akan kehilangan arah dan maknanyaa. Pendidikan mempunyai peranan terhadap perkembangan seseorang, hal tersebut dapat membantu seseorang dalam mengembangkan jati diri, dalam menemukan dan pengembangan jati diri seseorang memerlukan nilai-nilai untuk menata hidup sehingga memiliki tujuan arah hidup. Dengan kata lain pendidikan merupakan proses pembentukan sikap dan tingkah laku manusia dengan kualitas pendidikan yang baik di suatu bangsa maka kualitas sumber daya manusia tentu akan semakin baik pula.

Melihat kondisi saat ini, pembelajaran tidak bisa dilakukan seperti biasa karena adanya pandemi atau wabah virus corona yang mengharuskan siswa belajar di rumah. Pada tanggal 24 Maret Tahun 2020, Kemendikbud mengeluarkan Pelaksanaan Pembelajaran secara daring. Edaran tersebut menjelaskan bahwa sistem pembelajaran membantu di rumah melalui pembelajaran jarak jauh dilakukan untuk memberikan pengalaman belajar yang signifikan kepada siswa. Sesuai Permendikbud No. 15/2013 disebutkan pelaksanaan jarak jauh di masa pandemi ini memanfaatkan inovasi yang ada. Kemajuan ilmu pengetahuan dan inovasi memberikan pengaruh yang luas dalam ranah sekolahan, salah satunya adalah web. Seperti yang ditunjukkan oleh Manca dan Ranieri (2013) di masa seperti ini inovasi data merupakan jawaban atas pembelajaran yang intens. Berbagai macam media yang dapat 
dimanfaatkan untuk melakukan pembelajaran mencolok. Contoh media data seperti Google Homeroom, Whatsapp, Moodle, Edmodo, Google Meet, Zoom, dll (Asrifan, Festiawan dan Timorita 2020).. Penggunaan internet sangat membantu setiap penggunanya dalam melakukan aktivitas seperti proses belajar di masa pandemi. Pembelajaran yang sebelumnya dilakukan dengan interaksi secara langsung guru dan siswa bahkan antar-siswa lainnya kini harus dilakukan dengan sistem daring.

Merespon kebijakan kemendikbud agar pendidikan tetap berjalan maka SMAN 2 Salatiga mulai melaksanakan pembelajaran daring. Namun awal dilaksanakannya pembelajaran daring siswa mengalami kendala contohnya kendala sinyal dan kuota. Sementara itu, guru mengalami hambatan dalam mendominasi inovasi pembelajaran secara intens sehingga guru juga merasa sulit untuk mengajar. Berdasarkan fenomena tersebut peneliti tertarik melakukan penelitian guna untuk mendeskripsikan efektivitas penerapan pembelajaran daring di SMAN 2 Salatiga.

\section{KAJIAN PUSTAKA}

\section{Efektivitas Pembelajaran}

Menurut Ravianto (dalam Masruri, 2014) efektivitas merupakan sebuah standar penilaian seberapa optimal individu melakukan pekerjaannya. Pekerjaan dapat dikatakan efektif apabila capaian hasil baik biaya, waktu maupun mutu dapat dicapai. Dalam dunia pendidikan pembelajaran efektif merupakan pembelajaran yang mengarah pada keberhasilan seluruh komponen pembelajaran yang terorganisir guna untuk mencapai tujuan pembelajaran. Pembelajaran efektif mencakup keseluruhan tujuan pembelajaran baik yang berdimensi mental, fisik, maupun sosial (Suprijono, 2009). Pembelajaran efektif adalah gabungan yang disusun meliputi material, manusiawi, dan perlengkapan dengan mengarahkan siswa kearah yang lebih baik sesuai dengan potensi yang dimiliki dalam mencapai pembelajaran yang telah ditetapkan (Rohmawati, 2017).

Efektivitas pembelajaran adalah proses pelaksanaan belajar mengajar dimana menunjukkan output yang diperoleh. Indikator efektivitas pembelajaran menurut Wahyuddin dan Nurcahaya (2019) yaitu: a) Keberhasilan dalam belajar dapat dilihat dari output yang memenuhi kriterial ketuntasan minimal (KKM) yang telah ditentukan oleh pihak sekolah. b) Aktivitas belajar adalah sebuah proses dalam lingkungan sekolah, baik interaksi antara siswa dan pendidik atau siswa dengan yang lainnya sehingga karakter, keterampilan, tingkah laku dapat diamati dan dinilai. c) Kemampuan guru dalam mengelolah pembelajaran dimana dapat mempengaruhi hasil pelaksanaan dari pembelajaran .

\section{Pembelajaran Daring}

Istilah daring merupakan kepanjangan dari "dalam jaringan" yang merupakan suatu gerakan yang diselesaikan dengan memanfaatkan web dalam pembelajaran. Menurut Isman (2017) pembelajaran berbasis web adalah pemanfaatan jaringan web oleh siswa dalam sistem pembelajaran. Dengan adanya web dapat membantu dalam mengukur pembelajaran internet. Sebagaimana ditunjukkan oleh Permendikbud No. 109/2013 pendidikan jarak jauh adalah pembelajaran dengan menggunakan media secara jarak jauh. Perkembangan teknologi informasi saat ini, proses pembelajaran pun dapat dilakukan dengan beragam, salah satunya dengan metode daring (dalam jaringan) dimana metode ini menggunakan fasilitas internet untuk berbagai materi pembelajaran. Dari kedua pengertian di atas, dapat disimpulkan bahwa pembelajaran berbasis web dengan inovasi dalam sistem pembelajaran yang tidak dilakukakan dengan tatap muka dapat mempermudah siswa untuk belajar kapan pun dan dimana pun.

Dabbagh (dalam Hasanah, dkk 2020) kualitas dalam pembelajaran internet adalah sebagai berikut:1) Semangat belajar: semangat belajar dalam e-learning sangat penting karena kebebasan belajar setiap individu membuat perbedaan prestasi belajar. 2) Literacy terhadap teknologi: pemanfaatan teknologi dapat mengembangkan latihan pembelajaran dan pemahaman siswa dalam $e$ learning merupakan salah satu keberhasilan dalam melakukan pembelajaran e-learning. 3) Kemampuan berkomunikasi interpersonal: selain pemanfaatan teknologi, kemampuan berkomunikasi dan kemampuan interpersonal merupakan salah satu syarat keberhasilan dalam e-learning. 4) Berkolaborasi: pelaksanaan pembelajaran interaksi dan kolaborasi antara siswa dan siswa-siswi atau dengan guru pada sebuah forum yang ada. 5) Keterampilan untuk belajar mandiri: pelajar dilatih mencari, menemukan dan menyimpulkan sendiri dari apa yang telah dipelajari.

Dapat ditarik kesimpulan bahwa dalam pelaksanaan pembelajaran daring semangat belajar, interaksi dan penggunaan teknologi diperlukan untuk menunjang dan meningkatkan kegiatan belajar, 
melatih cara berpikir, berkomunikasi serta keterampilan. Hal tersebut dapat membantu pemecahan masalah dan membangun pengetahuan siswa dengan melakukan kolaborasi dan membentuk kelompokkelompok kecil kemudian membahasnya secara virtual.

Bilfaqih dan Qomarudin (2105) manfaat penelitian yaitu guna meningkatkan mutu pendidikan maka dilakukan pelatihan penggunaan multimedia secara efisien. Pelatihan yang berkualitas dalam pelaksanaan e-learning dapat meningkatkan pencapaian pendidikan. Sehingga dapat disimpulkan bahwa manfaat dari proses e-learning adalah kemajuan teknologi dan mampu meningkatkan kualitas pendidikan di Indonesia, serta mempermudah proses pembelajaran karena dapat dilakukan dimana saja dan kapan saja dengan akses materi pembelajaran yang mudah. dan mampu menjangkau siswa dengan cakupan yang luas. Menurut Rusman (2012) "E-learning dapat memberikan keleluasaan dalam mengakses kegiatan materi pembelajaran. Dari pendapat tersebut peneliti menyimpulkan bahwa kegiatan e-learning adalah kegiatan yang menggunakan teknologi untuk mendukung pembelajaran jarak jauh yang dapat dilakukan dimana saja dan kapan saja.

Pembelajaran daring juga mempunyai kelebihan dan kekurangan. Adapun kelebihan pembelajaran daring menurut Hadisi dan Muna (2015) sebagai berikut: a) Biaya dalam pembelajaran daring mampu meringankan biaya pelatihan. Artinya, dengan menghemat biaya pendidikan, tidak perlu mengeluarkan dana untuk keperluan peralatan dalam kelas. b) siswa dapat menyesuaikan waktu pembelajaran daring dan dapat mengakses setiap pelajaran kapanpun dan dimanapun. c) pembelajaran daring dapat menyesuaikan tempat belajar dan mengakses setiap materi pelajaran dimanapun, selagi komputer atau laptop bisa terhubung ke jaringan internet. d) Ketersediaan On-demand pembelajaran daring dapat mengakses dari berbagai tempat selagi masih terhubung internet, hal tersebut membantu menyelesaikan setiap tugas. Sedangkan kelemahan pembelajaran daring menurut Hadisi dan Muna (2015) yaitu: a) Dalam proses belajar mengajar pengajar dan siswa bahkan antar-siswa pun kurang adanya interaksi yang mengakibatkan keterlambatan dalam pembentukan sikap dan nilai-nilai atau values. b) Selama proses belajar- mengajar lebih mengarah ke pelatihan daripada mengajarkan pengetahuan-pengetahuan terkait dunia pendidikan. c) Kurangnya motivasi belajar yang tinggi oleh siswa cenderung gagal. d) Fasilitas internet yang tidak semua tempat tersedia (dalam hal masalah listrik, komputer, laptop, kuota bahkan tempat tinggal yang masih susah dengan sinyal) dapat menghambat dalam pembelajaran.

Dari penjelasan sebelumnya maka dapat ditarik kesimpulan mengenai kelebihan pembelajaran daring mempermudah proses pembelajaran, dapat mengakses materi dimana saja, melatih belajar mandiri. Sedangkan kekurangannya adalah siswa kurang memahami materi yang diberikan dan keterlambatan siswa dalam mengumpulkan setiap tugas yang diberikan.

\section{METODE PENELITIAN}

Pendekatan penelitian yang digunakan dalam penelitian ini adalah pendekatan kualitatif. Peneltian kualitatif lebih mengarah pada makna dan terikat nilai. Penelitian ini digunakan jika masalah belum jelas, untuk mengetahui makna yang tersembunyi, untuk memahami interaksi sosial, mengembangkan teori, memastikan kebenaran data dan meneliti sejarah perkembangan (Mamik, 2015). Jenis Penelitian ini yaitu model analisis deskriptif yaitu menggambarkan dari permasalahan yang ada. Menurut Rukajat (2018) model analisis deskriptif adalah sebuah prosedur pemecahan masalah yang diselidiki dengan menggambarkan keadaan subjek dan objek penelitian (seseorang, masyarakat, lembaga dan lain-lain) pada saat sekarang berdasarkan fakta-fakta yang tampak atau sebagaimana adanya. Deskripsi terperinci diperoleh dari pengamatan dan wawancara kepada kepala sekolah, pendidik dan siswa serta salah satu orang tua yang terlibat dengan topik dan artikel yang dipertimbangkan. Tempat penelitian di SMAN 2 Salatiga, dengan fokus penelitian penerapan metode e-learning dalam upaya meningkatkan efektivitas pelaksanaan daring di masa pandemi. Sumber informasi yang digunakan oleh peneliti dalam penelitian ini adalah sumber data primer yang diperoleh dari pengamatan langsung dan wawancara kepada kepala sekolah, guru, siswa (kelas X dan XI) dan orang tua. seseorang yang dijadikan modal dalam penelitian karena dianggap mengetahui isu-isu yang terjadi pada lingkungan yang diteliti (Arikunto, 2015). Sementara itu, sumber sekunder tambahan diperoleh daridokumen-dokumen dari sekolah.

Menurut Sugiyono (2019), teknik pengumpulan data merupakan tahapan utama dalam penelitian, dengan tujuan untuk mendapatkan data yang diperoleh. Karena itu, teknik pengumpulan data 
yang digunakan oleh peneliti adalah observasi, jenis observasi yang digunakan dalam penelitian ini adalah partisipasi pasif. Menurut Sugiyono (2019), partisipasi pasif adalah penelitian yang hanya memperhatikan, namun tidak mengambil bagian dalam kegiatan tersebut.. Peneliti melakukan pengamatan di sekolah SMAN 2 Salatiga. Wawancara, jenis wawncara yang digunakan adalah wawancara terstrukturi. Dokumentasi digunakan untuk mensurvei informasi yang telah dikumpulkan.

\section{HASIL PENELITIAN DAN PEMBAHASAN}

\section{Pembelajaran Daring di Masa Pandemi Covid}

Yunus dan Rezki (2020) semenjak covid-19 yang bermula dari China kemudian masuk di berbagai negara termasuk Indonesia, pemerintah langsung mengambil keputusan untuk melakukan Work From Home selama empat belas hari, namun semakin hari semakin banyak orang yang terkena covid-19. Untuk mengurangi penyebaran covid - 19 maka berbagai negara menerapkan social dan physical distancing (pembatasan jarak sosial) atau pengurangan interaksi individu dengan individu dan kelompok dengan kelompok karena hal tersebut dapat memicu cepatnya penyebaran covid - 19 dimana orang yang sudah tertular virus belum di isolasi karena belum ada gejala sama sekali Smith dan Freedman (2020). Dengan menetapkannya sosial dan physical distancing pemerintah mewajibkan warganya untuk stay at home (dengan melakukan work from home, belajar, beribadah di rumah). Menindaklanjuti kebijakan pemerintah dimana pendidikan harus tetap berjalan di masa pandemi maka SMAN 2 Salatiga melaksanakan pembelajaran daring. Tentunya setiap program-program yang sebelumnya harus dilaksanakan secara luring harus di tunda bahkan dilaksanakan dengan daring.

Pelaksanaan e-learning di masa pandemi bertujuan untuk menjamin kesehatan dan keselamatan guru, siswa, dan staf-staf sekolah. Sehingga pelaksanaan pembelajaran dapat berlangsung dengan aman, tanpa harus berinteraksi dengan banyak individu untuk mengurangi penyebaran virus Corona (Ardiyanti, dkk 2020). E-learning dapat menjadi pengalaman baru bagi guru dalam memanfaatkan IT. Terciptanya lingkungan belajar adalah bagian penting dalam mewujudkan lingkungan belajar mandiri dan kondusif. Pada era pendidikan 4.0 lingkungan belajar lebih mengarah pada pengembangan fasilitas dengan memberikan kebebasan kepada siswa dalam kegiatan pembelajaran dengan penyediaan dukungan yang fleksibel, mudah diakses yaitu pembelajaran melalui internet (Drouin et al., 2013). Sejalan dengan penelitian yang dilakukan Hatmo (2021) terkait dampak pembelajaran selama pandemic Covid-19.

Lembaga pendidikan adalah suatu institusi atau tempat berlangsungnya proses pembelajaran yang berfungsi untuk membina manusia, mengarahkan tingkah laku seseorang dalam memperoleh tujuan hidup yang lebih baik melalui interaksi di lingkungan sekitar (keluarga, masyarakat dan sekolah) (Putri dkk, 2013). Adaptasi di masa pandemi lembaga pendidikan membutuhkan sarana dan prasarana sebagai faktor pendukung berjalannya pembelajaran daring yang maksimal. Oleh sebab itu, untuk mengurangi terjadinya hambatan dalam proses pembelajaran daring lembaga pendidikan menyediakan sarana dan prasarana dengan baik. Untuk menunjang pembelajaran daring sarana dan prasarana yang harus dipersiapkan yaitu komputer, internet, software penunjang, hardware penunjang dan tenaga ahli (Johan dan Riche, 2008). Layanan pendidikan berbasis sarana yang beragam di SMAN 2 Salatiga pun sudah tersedia, baik aplikasi pembelajaran daring dan bantuan kuota internet sebanyak satu kali dalam sebulan dari sekolah. Sedangkan, sebagian prasarana juga digunakan namun hanya sebagai penunjang beberapa pendidik dalam proses mengajar seperti laboratorium komputer.

Saat ini konteks pendidikan terfokus pada inovasi dalam penggunaan informasi, internet dan teknologi secara maksimal (Oktavian dan Aldya, 2020). Pendidik dituntut mendesain pembelajaran yang kreatif dan inovatif. Berhasil tidaknya pembelajaran yang dilaksanakan tergantung dari cara pendidik dalam merancang, membuat materi, dan melakukan sebuah inovasi metode pembelajaran. Tentunya diperlukan pemahaman akan teknologi yang mengarahkan pendidikan lebih maju untuk menuju sistem edukasi 4.0. Revolusi 4.0 merupakan perubahan yang terjadi secara besar-besaran di berbagai bidang lewat perpaduan teknologi yang berdampak di dunia pendidikan (Oktavian dan Aldya, 2020).

Selain pendidik ada peran penting orang tua dalam menunjang dan memastikan siswa dalam membantu proses pembelajaran daring. Masalah lain yang dialami oleh pendidik kenyataannya pada awal proses pelaksanaan belajar daring pendidik mengalami kesulitan dalam menggunakan media pembelajaran. Oleh karena itu pihak kurikulum melakukan pelatihan penggunaan media yang di pakai 
dalam pembelajaran daring. Media yang digunakan dalam pelaksanaan pembelajaran daring sekolah yaitu Jagaratu (pertengahan bulan Maret- Desember 2020). Namun pada awal tahun 2021 pihak sekolah mengganti dengan menggunakan Mediadidik.com. Begitu pula, hal lain yang dirasakan oleh siswa mengalami kendala jaringan yang sering kali terputus karena terbatasnya akses internet. Oleh karena itu pihak sekolah mengizinkan siswa menggunakan fasilitas sekolah seperti laboratorium komputer dalam pembelajaran daring.

\section{Efektivitas Pembelajaran Daring}

Menurut Gibson (Harmani dan Cilegon, 2020) efektivitas adalah proses berkaitan dengan hasil yang dicapai seseorang atau suatu kelompok kerja sama antara orang-orang yang diadakan untuk mencapai tujuan bersama. Efektivitas menekankan pada pelaksanaan tugas, kinerja dan tanggung jawab dengan tujuan yang telah direncanakan sebelumnya. Begitu pun dalam pendidikan dimana dalam kegiatan pembelajaran pendidik tidak hanya memberikan materi pembelajaran tetapi mengubah cara berpikir siswa dari yang sulit dipelajari menjadi mudah mempelajarinya.

Dari hasil wawancara yang dilakukan, pelaksanaan e-learning telah berjalan dengan baik. Meskipun demikian, kelangsungan pelaksanaan daring di SMAN 2 Salatiga belum maksimal mengingat siswa hanya diberikan materi, tugas dan ulangan. Guru juga tidak menyadari apakah dengan mengerjakan tugas-tugas yang diberikan siswa sudah memahami atau belum. Belajar juga untuk mendapatkan, mencerna, dan melihat (secara intelektual) latihan yang diberikan oleh guru tetapi penting juga untuk mengajarkan karakter dan sikap (emosional) seperti halnya kemampuan dan kapasitas untuk bertindak (psikomotor). Seorang guru memiliki tugas utama, lebih tepatnya memiliki pilihan untuk memahami standar dan unsur kelayakan dalam memanfaatkan inovasi selama pembelajaran dengan siswa (Putrawangsa dan Hasanah, 2018). Pembelajaran dengan pemanfaatan inovasi data dan korespondensi dapat terlaksana dengan baik jika tugas guru dalam pembelajaran adalah sebagai fasilitator untuk mempermudah siswa belajar.

Hasil belajar dapat tercapai bila terpenuhinya dua petunjuk yang menyertainya:

1) Kapasitas individu dalam memahami materi pembelajaran dengan prestasi tinggi, baik secara mandiri maupun dalam kelompok.

2) Karakter, sikap dan sifat dalam pembelajaran/pendidikan dalam prestasi belajar secara kelompok atau individu (Susanto, 2013).

Jadi hasil belajar adalah ketercapaian siswa dalam mengubah contoh penalaran, tingkah laku, dan kemampuan yang dapat mempengaruhi proses pembelajaran.

Dari penjelasan diatas penyebab kurang efekttif pelaksanaan daring perbaikan yang diberikan agar pelaksanaan daring kedepannya lebih baik yaitu dengan meningkatkan kreativitas tenaga pendidik dalam hal memanfaatkan media pembelajaran agar siswa tidak merasa jenuh dan memudahkan siswa dalam memahami materi misalnya mind map, power point dan video animasi. pendidik harus belajar dalam pemanfaatan teknologi dan dituntut dapat merancang pembelajaran yang efektif, efisien, dan mudah dipahami oleh siswa. Kemampuan dalam menggunakan teknologi informasi dan komunikasi secara optimal sebagai alat bantu dalam proses pembelajaran (Hanum, 2013).

\section{SIMPULAN}

Pelaksanaan pembelajaran daring yang dilakukan di SMAN 2 Salatiga pada awal masa pandemi mengalami berbagai kendala yang dialami oleh siswa bahkan guru. Adanya kendala tersebut maka pihak sekolah memberikan bantuan kepada siswa dalam bentuk kuota internet, sedangkan untuk guruguru pihak sekolah melakukan pelatihan penggunaan teknologi dan web apa yang akan digunakan. Seiring berjalannya waktu guru-guru pun dapat menggunakannya dan proses pembelajaran pun dapat berjalan dengan baik. Namun untuk efektivitas pelaksanaan pembelajaran belum efektif dikarenakan terkadang siswa ataupun guru terkendala dengan koneksi internet yang buruk.

\section{SARAN}

Selama pelaksanaan pembelajaran daring hendaknya guru meningkatkan kreativitas agar pembelajaran tidak monoton sehingga siswa tidak merasa jenuh. Guru harus memanfaatkan teknologi dengan optimal misalnya mencari di youtune tips-tips pembelajaran daring yang interaktif. Penelitian ini jauh dari kata sempurna maka, bagi peneliti selanjutnya dengan tema seperti ini dapat memberikan inovasi baru terkait kajian penelitian lain terhadap pembelajaran daring. 
Efektivitas Pembelajaran Daring Pada Masa Covid di SMAN 2 Salatiga

(Irna E. Samoling, Bambang Ismanto, Lelahester Rina)

\section{DAFTAR PUSTAKA}

Ardiyanti, N. M. D., Mahayukti, G. A., \& Sugiarta, I. M. (2020). Evaluasi Proses Pembelajaran Matematika Secara Daring di SMAN Kota Singaraja. Journal of Chemical Information and Modeling, 18(9), 136-157.

Arikunto, Suharsimi. (2015). Prosedur Penelitian, Suatu Pendekatan Praktik. Jakarta: PT. Rineka Cipta

Asrifan, A., Festiawan, R., \& Timorita Yulianti, R. (2020). Adaptasi Kebiasaan Baru Masyarakat Indonesia Pada Era Pandemi COVID-19: Tinjauan Berbagai Disiplin Ilmu (Issue December). https://www.researchgate.net/publication/347982809

Bilfaqih, Y dan Qomarudin, N. (2015). Esensi Pengembangan Pembelajaran Daring. Yogyakarta: DEEPUBLISH.

Drouin, M., Hile, R. E.; Vartanian, L. R., \& Webb, J. 2013. Student Preferences for Online Lecture Formats. Quarterly Review of Distance Education, 14(3). pp. 151-162.

Fajarini, U. (2014). Peranan Kearifan Lokal Dalam Pendidikan Karakter. SOSIO DIDAKTIKA: Social Science Education Journal, 1(2). https://doi.org/10.15408/sd.v1i2.1225

Hadisi, dan Muna. (2015). Pengelolaan Teknologi Informasi Dalam Menciptakan Model Inovasi Pembelajaran ( pembelajaran daring ). Jurnal Al-Ta'dib, 8, 127-132.

Hatmo, S. H. D. (2021). Dampak Pandemi Covid-19 Terhadap Efektivitas Pembelajaran Jarak Jauh Secara Daring. Scholaria: Jurnal Pendidikan dan Kebudayaan, 11(2), 115-122.

Harnani, S. S. P., \& Cilegon, G. pada Mt. N. 1 K. (2020). Efektivitas Pembelajaran Daring Di Masa Pandemi Covid-19. Https://Bdkjakarta.Kemenag.Go.Id/, 21(September), 53-56. https://bdkjakarta.kemenag.go.id/berita/efektivitas-pembelajaran-daring-di-masa-pandemicovid-19

Hanum, N. S. (2013). Keefetifan e-learning sebagai media pembelajaran (studi evaluasi model pembelajaran e-learning SMK Telkom Sandhy Putra Purwokerto). Jurnal Pendidikan Vokasi, 3(1), 90-102. https://doi.org/10.21831/jpv.v3i1.1584

Hasanah, dkk. 2020. Analisis Aktivitas Belajar Daring Mahasiswa Pada Pandemi COVID-19. Jurnal Pendidikan. Volume 1 No.1.

Isman, M. (2017). Pembelajaran Moda dalam Jaringan (Moda Daring). The Progressive and Fun Education Seminar, 586-588.

Johan \& Riche. C. (2008) Pengaruh Pesan Visual Web terhadap Pembentukan Motivasi Belajar Secara Visual. Dalam Mimbar Pendidikan UPI, Vol. XXXII No.3, h. 22.

Mamik. (2015). Metode Kualitatif. In Zifatama Publisher (Vol. 53, Issue 9).

Manca, S., \& Ranieri, M. (2013). Is it a tool suitable for learning? A critical review of the literature on Facebook as a technology-enhanced learning environment. Journal of Computer Assisted Learning, 29(6), 487-504. https://doi.org/10.1111/jcal.12007

Masruri. (2014). Analisis Efektifitas Program Nasional Pemberdayaan Masyarakat Mandiri Perkotaan. Padang: Akademia Permata

Oktavian, R., \& Aldya, R. F. (2020). Efektivitas Pembelajaran Daring Terintegrasi di Era Pendidikan 4.0. Didaktis: Jurnal Pendidikan Dan Ilmu Pengetahuan, 20(2), 129-135. https://doi.org/10.30651/didaktis.v20i2.4763

Prayitno. (2009). Dasar Teori dan Praksis Pendidikan. Grasindo.

Putrawangsa, S., \& Hasanah, U. (2018). Integrasi Teknologi Digital Dalam Pembelajaran Di Era Industri 4.0. Jurnal Tatsqif, 16(1), 42-54. https://doi.org/10.20414/jtq.v16i1.203 
Putri, Kunia, C., \& Noor, trisna insan. (2013). Optimalisasi Peran Lembaga Pendidikan Untuk Mencerdaskan Bangsa. Analisis Pendapatan Dan Tingkat Kesejahteraan Rumah Tangga Petani, 53(9), 1689-1699.

Rohmawati, A., (2017). Efektivitas Pembelajaran. Jurnal Pendidikan Usia Dini, 9(1), 15 - 32. https://doi.org/10.21009/JPUD.091.02

Rukajat, Ajat. (2018). Pendekatan Penelitian Kuantitatif: Quantitative Research Approach. Yogyakarta: Deepublish

Rusman. (2012). Manajemen Kurikuulum. Jakarta. Rajawali Pers.

Smith, A. W., \& Freedman, D. O. (2020). Isolation, quarantine, social distancing and community containment: pivotal role for old-style public health measures in the novel coronavirus (2019nCoV) outbreak. Journal of Travel Medicine.

Sugiyono. (2019). Metodologi Penelitian Kuantitatif, Kualitatif, dan R\&D. Bandung: Alfabeta

Suprijono, A., (2009). Cooperative Learning Teori dan Aplikasi PAIKEM. Yogyakarta: Pustaka Pelajar.

Susanto, (2013) Teori Belajar dan Pembelajaran di Sekolah Dasar, (Jakarta: Kencana Prenada Media Group. h.3

Wahyuddin, W., \& Nurcahaya, N. (2019). Efektivitas Pembelajaran Matematika Melalui Pembelajaran Aktif Tipe Everyone Is a Teacher Here (Eth) Pada Siswa Kelas X Sma Negeri 8 Takalar. Al Khawarizmi: Jurnal Pendidikan Dan Pembelajaran Matematika, 2(1), 72. https://doi.org/10.22373/jppm.v2i1.4500

Yunus, N. R., \& Rezki, A. (2020). Kebijakan Pemberlakuan Lock Down Sebagai Antisipasi Penyebaran Corona Virus Covid-19. SALAM: Jurnal Sosial Dan Budaya Syar-I, 7(3). https://doi.org/10.15408/sjsbs.v7i3.15083 